\title{
STATUS HAK ATAS TANAH PENDUDUK DESA DALAM KAWASAN HUTAN PERUM PERHUTANI
}

\author{
Fatimiah Azzahra \\ Program Studi Ilmu Hukum Universitas Brawijaya \\ Jl. MT. Haryono 169 Malang \\ Email:miafaza6@gmail.com
}

\begin{abstract}
: this article aims to discuss the conflict of tenure rights between Perhutani and the community and the status of land held by the community after the entry into force of Presidential Regulation No. 86 of 2018 concerning Agraria Reform. The study uses a sociological juridical method. The location of the study is in the forest area of Perhutani Public Corporation, Malang Regency. Data collection techniques using observation, interviews, and documentation. The results of the study show that conflicts over ownership of land rights between Perhutani and the community have been going on for a long time. Physically the land has been controlled by the community since the Dutch colonial era and passed down from generation to generation. The granting of permission to manage the land and payment of land tax strengthened the community's argument about land ownership. The land status which is the object of the dispute is based on Presidential Regulation No. 86 of 2018 concerning Agrarian Reform became the authority of Perhutani Public Corporation. Communities can get ownership rights or get land compensation if the Ministry of Forestry releases the land.
\end{abstract}

Kata kunci : Agraria Reform, Perhutani Public Corporation, Land's Right.

\begin{abstract}
Abstrak: tujuan penulisan artikel ini adalah untuk membahas tentang konflik penguasaan hak atas tanah antara Perum Perhutani dengan masyarakat dan status tanah yang dikuasai masyarakat setelah berlakunya Peraturan Presiden No. 86 Tahun 2018 Tentang Reforma Agraria. Kajian menggunakan metode yuridis sosiologis dengan lokasi kajian di lahan kawasan hutan Perum Perhutani Kabupaten Malang. Teknik pengumpulan data menggunakan observasi, wawancara, dan dokumentasi. Hasil kajian menunjukkan bahwa konflik kepemilikan hak atas tanah antara Perum Perhutani dengan masyarakat telah berlangsung sejak lama. Secara fisik tanah telah dikuasai masyarakat sejak jaman penjajahan Belanda dan diwariskan secara turun temurun. Pemberian ijin mengelola lahan dan pembayaran SPPT PBB memperkuat argumentasi masyarakat tentang kepemilikan tanah. Status tanah yang menjadi obyek sengketa berdasarkan Peraturan Presiden No. 86 Tahun 2018 tentang Reforma Agraria menjadi kewenangan Perum Perhutani. Masyarakat dapat mendapatkan hak milik atau mendapatkan penggantian tanah (tukar guling) jika Kementerian Kehutanan melepaskan tanah tersebut.
\end{abstract}

Kata kunci : Reforma Agraria, Perum Perhutani, Hak Atas Tanah.

\section{PENDAHULUAN}

Tanah berperan penting dalam kehidupan pribadi, bermasyarakat dan bernegara. Segalaaktifitas penunjang kelangsungan hidup manusia dilakukan diatas tanah. Sebagai komoditas pemenuhan kebutuhan hidup pokok berupa sandang, pangan dan papan, manusia akan terus berupaya untuk menguasai dan memiliki tanah demi meningkatkan kesejahteraan hidupnya. Hubungan manusia dengan tanah bersifat relatif, artinya kekuasaan manusia terhadap tanah tidak dapat tanpa batas, dan semua manusia dapat berhubungan dengan tanah, akan tetapi semua manusia akan membutuhkan 
tanah untuk hidupnya. Jadi, meskipun orang tidak mempunyai hubungan dengan tanah tetap ia mempunyai hak untuk menerima manfaat dari tanah (Sumardjono, 2011:14).

Pemanfaatan tanah sebagai wujud dari pengelolaan sumber daya alam serta lingkungan hidup merupakan tanggung jawab bersama antara pemerintah dan masyarakat sebagaimana dijelaskan dalam UU Nomor 23 Tahun 1997 tentang Pengelolaan Lingkungan Hidup (Noor, 2018). Aturan ini menjadi salah satu instrumen demi mewujudkan ketentuan dalam UUD Negara Republik Indonesia yang mengamanatkan bahwa sumber daya alam dan kekayaan yang terkandung didalamnya dikuasai negara untuk kemakmuran rakyat. Ketentuan ini mengandung pengertian kepemilikan (ownership) (Fadhilah, 2016). Maka dari itu, pemerintah berwenang untuk membuat aturan-aturan yang terkait dengan pengelolaan sumber daya alam, termasuk tentang kehutanan.

Undang-Undang Nomor 41 Tahun 1999 tentang Kehutanan dalam Pasal 1 angka 2 menyatakan bahwa "Hutan adalah suatu kesatuan ekosistem berupa hamparan lahan berisi sumber daya alam hayati yang didominasi pepohonan dalam persekutuan alam lingkungannya", yang satu dengan lainnya tidak dapat dipisahkan. Sedangkan kawasan hutan adalah wilayah tertentu yang ditunjuk dan atau ditetapkan oleh pemerintah untuk dipertahankan keberadaannya sebagai hutan tetap. Berdasarkan pengertian hutan dan kawasan hutan menurut Undang-Undang Kehutanan tersebut, dapat disimpulkan bahwa hutan adalah pengertian fisik atau ekologi sedangkan kawasan hutan adalah pengertian yuridis atau status hukum (Supriadi, 2010:1). Kewenangan untuk menetapkan status hutan berada di tangan pemerintah pusat. Hutan berdasarkan statusnya terdiri dari hutan negara dan hutan hak. Hutan negara adalah hutan yang berada pada tanah yang tidak dibebani hak atas tanah, sedangkan hutan hak adalah hutan yang berada pada tanah yang dibebani hak atas tanah. Hutan negara dapat berupa hukum adat, yaitu hutan negara yang diserahkan pengelolaanya kepada masyarakat hukum adat (rechtsgemeenschap). Hutan adat ditetapkan oleh pemerintah sepanjang menurut kenyataannya masyarakat hukum adat yang bersangkutan masih ada dan diakui keberadaannya. Apabila dalam perkembangannya masyarakat hukum adat yang bersangkutan tidak ada lagi, maka hak pengelolaan hukum adat kembali ke pemerintah (vide Pasal 5 ayat (1) (Pamulardi, 2005:21). Pasal 4 ayat (1) UU Nomor 04 Tahun 1999 tentang Kehutanan menyatakan bahwa semua hutan di dalam wilayah Republik Indonesia termasuk kekayaan alam yang terkandung didalamnya dikuasai oleh negara untuk sebesar-besarnya kemakmuran rakyat.

Terkait mengenai penguasaan dan pemilikan dalam hukum kehutanan ini pemerintah Indonesia baru-baru ini membuat peraturan atau menggulirkan program Reforma Agraria dalam rangka mewujudkan pemerataan dan pembangunan yang berbasis keadilan bagi seluruh rakyat Indonesia. Dalam ranah kehutanan ini program pemerintah dalam rangka pemerataan pembangunan yang berbasis keadilan bagi seluruh rakyat Indonesia, yakni program TORA (Tanah Obyek Reforma Agraria) untuk menjamin kepastian hukum dan pelaksanaan program tersebut tetap harus dilandasi dasar hukum yang kuat dan kokoh, yang mana terlampir dalam Peraturan Presiden Nomor 86 Tahun 2018 Tentang Reforma Agraria. Pasal 1 ayat (1) menyatakan "Reforma agraria adalah penataan kembali struktur penguasaan, pemilikan, penggunaan, dan pemanfaatan tanah yang lebih berkeadilan melalui Penataan Aset dan disertai dengan Penataan Akses untuk kemakmuran rakyat Indonesia". Permasalahan ini terkait dengan konflik-konflik tenurial yang salah satunya disebabkan oleh perbedaan penafsiran terhadap hukum positif yang berlaku di masyarakat terutama masyarakat desa contohnya seperti tanah hutan atau tanah negara yang ditempati oleh masyarakat 
desa dan perspektif masyarakat desa bahwa tanah tersebut adalah miliknya karena telah menempati lama dan selalu membayar pajak. Pemikiran tersebut didasarkan pada Pasal 24 ayat (2) Peraturan Pemerintah Nomor 24 Tahun 1997 Tentang pendaftaran tanah yang mengatur bahwa apabila tidak terdapat alat bukti tentang kepemilikan tanah maka dapat menggunakan alat bukti lain yaitu penguasaan fisik. Penguasaan terhadap tanah selama 20 tahun oleh pemohon atau pendahulunya dengan syarat penguasaan tersebut dilakukan dengan itikad baik dengan kesaksian orang yang dapat dipercaya dan tidak ada yang menolak atau menggugat terhadap pengumuman tentang upaya pendafataran tanah yang diajukan oleh pihak yang bersangkutan.

Perum Perhutani adalah badan usaha milik negara di bidang kehutanan yang diberi pelimpahan kewenangan pengelolaan hutan negara yang berada di provinsi jawa barat, jawa tengah dan jawa timur serta provinsi Banten kecuali hutan konservasi. Luas kawasan hutan negara yang dikelola Perum Perhutani lebih kurang 2.429. 203 hektar, terdiri dari hutan produksi seluas 1.767.304 hektar dan hutan lindung 658.902 hektar. Kewenangan untuk mengelola hutan - hutan tersebut telah diatur dalam Peraturan Pemerintah Nomor 72 Tahun 2010 tentang Perusahaan Umum (Perum) Kehutanan Negara, dapat dilihat pada pasal 3 Peraturan Pemerintah Nomor 72 Tahun 2010 yang berbunyi: "Dengan Peraturan Pemerintah ini, Pemerintah melanjutkan penugasan kepada perusahaan untuk melakukan pengelolaan hutan di hutan negara yang berada di provinsi Jawa Barat, provinsi Jawa Tengah, provinsi Jawa Timur, provinsi Banten, kecuali hutan konservasi, berdasarkan prinsip pengelolaan hutan lestari dan prinsip tata kelola perusahaan yang baik".

Ketentuan lain yang menjadi landasan hukum Perum Perhutani dalam melaksanakan pengelolaan hutan dapat dijumpai dalam penjelasan pasal 21 UU Kehutanan, yaitu: "Pengelolaan hutan pada dasarnya merupakan kewenangan pemerintah (pusat) dan atau pemerintah daerah, namun mengingat berbagai kekhasan daerah serta kondisi sosial dan lingkungan yang sangat berkaitan dengan kelestarian hutan dan kepentingan masyarakat luas yang membutuhkan kemampuan pengelolaan secara khusus, maka pelaksanaan pengelolaan hutan di wilayah tertentu dapat dilimpahkan kepada BUMN yang bergerak di bidang kehutanan, baik berbentuk perusahaan umum (Perum), perusahaan jawatan (Perjan), maupun perusahaan perseroan (Persero), yang pembinaannya di bawah Menteri Kehutanan" (Supriyadi, 2013:104). Desa Sanankerto konon dari ceritanya desa Sanankerto berasal dari salah satu dukuh/Dusun didesa Sananrejo yang mempunyai nama dukuh/dusun Singgahan . Karena batas desa Sananrejo dengan dukuh /dusun Singgahan terletak jauh di Timur sungai Lesti, Akhirnya pada th 1910 mulailah dibentuk Kepala Desa sendiri yang kemudian oleh pihak Kecamatan di namamkan Desa Sanankerto hingga sekarang ini (Rencana Pembangunan Desa Jangka Menengah Desa, 2014:9).

Perekonomian Desa Sanankerto secara umum didominasi pada sektor pertanian yang sistem pengelolaanya masih sangat tradisional (pengolahan lahan, pola tanam mapun pemilihan komoditas produk pertaniannya). Produk pertanian desa Sanankerto untuk lahan basah (sawah) masih monoton pada unggulan padi dan sedikit palawija, hal ini diakibatkan adanya struktur tanah yang mungkin belum tepat untuk produk unggulan pertanian diluar sentra padi dan persoalan mendasar lainnya adalah sistem pengairan yang kurang baik sehingga berdapak adanya kekurangan air jika pada saat musim kemarau. Oleh karenanya harus ada langkah strategis dalam mengatasi persoalan pertanian dengan melakukan berbagai upaya, diantaranya: perbaikan sistem irigasi/pengairan, penggunaan 
teknologi tepat guna perbaikan pola tanam dan pemilihan komoditas alternatif dengan mengkomunikasikannya kepada pihak-pihak terkait (dinas pengairan, dinas pertanian). Sedangkan untuk lahan kering (tegal) produk unggulan masih di dominasi oleh tanaman tebu, di samping itu masih banyak lahan yang belum termanfaatkan secara produktif untuk meningkatkan perekonomian masyarakat. Langkah alternatif yang bisa dilakukan untuk mengatasi hal tersebut adalah melakukan penyuluhan-penyuluhan untuk meningkatkan pemanfaatan lahan pengadaan bibit-bibit tanaman produktif dengan melibatkan instasi terkait (dinas kehutanan, dinas pertanian dan perkebunan Rencana Pembangunan Desa Jangka Menengah Desa, 2014:12).

Permasalahan ini berkaitan dengan sengketa tanah yang melibatkan suatu masyarakat dengan Perum Perhutani. Status tanah tersebut telah berlangsung sejak lama dan meskipun telah dilakukan berbagai upaya penyelesaian, permasalahan tersebut belum terselesaikan hingga saat ini. Adapun duduk permasalahannya adalah sebagai berikut: Adalah sebuah desa yang bernama Sanankerto, yang terletak di Kecamatan Turen, Kabupaten Malang.

Sanankerto adalah sebuah desa otonom yang dulunya merupakan salah satu dusun milik desa Sananrejo (desa yang bersebelahan dengan desa Sanankerto) sebelum tahun 1910. Desa yang memiliki luas 265.118 Ha tersebut memiliki berbagai potensi yang mendukung untuk pembangunan nasional. Dalam hal ini yang dimaksud adalah kekayaan sumber daya alam (SDA) berupa hutan bambu dan tanah yang memiliki intensitas tanah yang sangat baik untuk perkembangbiakkan segala jenis tanaman yang hidup di iklim tropis.

Berdasarkan deskripsi dalam latar belakang, terdapat isu hukum yang layak untuk dibahas, yaitu: (1) kasus konflik kepemilikan tanah yang berada di Kawasan hutan Perum Perhutani, dan (2) status hak atas tanah penduduk desa dalam kawasan hutan Perum Perhutani (KPH) Malang ditinjau dari Peraturan Presiden Nomor 86 Tahun 2018 Tentang Reforma Agraria.

\section{METODE}

Pembahasan isu hukum menggunakan metode yuridis sosiologis sosiologis yaitu mengkaji hukum yang dalam ranah hukum kenyataan, penelitian ini meneliti dan mengkaji berlakunya hukum dimasyarakat (Muhammad, 2004:155). Kajian menggunakan pendekatan kualitatif yang "berusaha mengungkapkan gejala secara menyeluruh dan sesuai dengan konteks (holistik-kontekstual) melalui pengumpulan data dari latar alami dengan memanfaatkan diri peneliti sebagai instrumen kunci" (Saukah, 2002:20).

Bogdan dan Taylor (Moleong, 2005:5) mendefinisikan kualitatif sebagai "prosedur kajian yang menghasilkan data deskriptif berupa kata-kata tertulis atau lisan dari orang-orang dan perilaku yang diamati”. Pendekatan kualitatif ini akan menghasilkan data deskriptif dalam bentuk ucapan ataupun tulisan dan perilaku orang yang diamati. Penelitian deskriptif adalah "mengurutkan atau menafsirkan data yang berkenaan dengan fakta, keadaan, variabel, dan fenomena yang terjadi saat penelitian berlangsung dan menyajikan apa adanya" (Subana dan Sudrajat, 2001:59). Menurut Sudjana dan Ibrahim, penelitian deskriptif adalah "penelitian yang berusaha mendiskripsikan suatu gejala, peristiwa, kejadian yang terjadi pada saat sekarang" (Sudjana, 198:64).

Lokasi kajian mengenai status hak atas tanah penduduk desa dalam kawasan hutan perum perhutani ini berada di KPH Malang. Tinjauan didasarkan pada Peraturan Presiden Nomor 86 Tahun 2018 tentang Reforma Agraria. Pengumpulan data menggunakan observasi, wawancara dan dokumentasi. Analisis data menggunakan analisis interaktif, mulai dari mengumpulkan data, mereduksi data, mengolah data, dan menyajikan data.

\section{HASIL DAN PEMBAHASAN}




\section{Konflik Kepemilikan dan Status Hak Atas di Kawasan Hutan Perum Perhutani (KPH)}

Permasalahan kepemilikan atau penguasaan tanah antara masyarakat penduduk Dusun Kampung anyar Desa Sanankerto dengan Perum Perhutani melalui Kesatuan Pemangkuan Hutan Malang bermula terhadap tanah negara bekas kebun kopi zaman kolonial Belanda yang dikenal oleh masyarakat desa sebagai blok Andeman dengan luas 94,8 Ha. Sebelum menjadi objek yang disengketakan dengan Perum Perhutani, blok Andeman telah dikelola terlebih dahulu oleh masyarakat sejak tahun 1910. Mayoritas mata pencaharian penduduk pada saat itu adalah petani/pekebun dan buruh tani. Sebagai masyarakat pedesaan yang berada di kawasan hutan, masyarakat bergantung pada kekayaan sumber daya alam yang ada di dalam blok Andeman sebagai sumber penghidupan sehari-hari. Pada tahun 1951, sebagian masyarakat mulai menetap di wilayah Andeman sehingga menjadi sebuah pedukuhan/ dusun baru yang bernama Kertomulyo/ Kampung Anyar.

Penduduk yang ada di dusun tersebut pada mulanya terdiri atas 51 Kepala Keluarga dengan kapasitas jumlah sebesar 246 Jiwa. Seluruh masyarakat yang ada di dusun tersebut adalah petani/ pekebun dan buruh tani sehingga menjadikan wilayah Andeman sebagai lahan garapan serta pemukiman. Masyarakat setempat telah mengetahui bahwa mereka bukan pemilik yang sah terhadap tanah yang digarap. Hal ini dikarenakan seluruh tanah yang tidak bisa dibuktikan kepemilikan status hak atas tanah tersebut, maka kembali kepada negara sehingga menjadi Tanah Negara, dan pada saat ini masyarakat desa mengajukan konflik tanah ini sebagai tanah objek reforma agraria yang diatur dan ditinjau dari Peraturan Presiden Nomer 86 Tahun 2018 Tentang Reforma Agraria dalam Pasal 1 ayat 4 yakni Tanah Objek Reforma Agraria yang selanjutnya disingkat TORA adalah tanah yang dikuasai oleh negara dan/atau tanah yang telah dimiliki oleh masyarakat untuk diredistribusi atau dilegalisasi. Hingga saat ini masih dalam penanganan dan sudah diajukan ke provinsi dan akan menjadi kewenangan pusat hingga sekarang penanganan ini belum selesai masih dalam proses dan menunggu keputusan. Sejak tahun 1951, masyarakat yang ada di wilayah Andeman telah membayar Iuran Pembangunan Daerah (IPEDA) sebagaimana ketentuan Peraturan Pemerintah Pengganti Undang-Undang No. 11 Tahun 1959 tentang Pajak Hasil Bumi.

Pasal 4 Undang-Undang No.11 Tahun 1959 mengatur bahwa Iuran Pembangunan Daerah (IPEDA) ditujukan kepada wajib pajak yang memiliki hak kebendaan baik berupa hak kepemilikan, penggunaan, pengusahaan atas tanah. Pemberian Pajak Bumi dan Bangunan kepada seluruh masyarakat dusun Kampung Anyar memberikan keuntungan dan atau kedudukan sosial ekonomi yang lebih baik bagi orang/badan yang mempunyai hak atau memperoleh manfaat darinya. Pernyataan tersebut adalah status dari para penduduk yang memperoleh manfaat dari Blok Andeman yang merupakan tanah yang dikuasai langsung oleh negara. Pada tahun 1986, Badan Pertanahan Nasional Tingkat II Malang dengan Pemerintahan Kecamatan Turen mempertimbangkan kondisi petani penggarap yang ada di Dusun Kampung Anyar.

Badan Pertanahan Nasional Tingkat II Malang menerbitkan surat izin menggarap (SIM) untuk meningkatkan keadaan sosial ekonomi penduduk desa Sanankerto khususnya dusun Kampung Anyar. Surat izin menggarap didasarkan pada Surat Keputusan Menteri Agraria No.509/Ka/1961 tentang Pernyataan Penguasaan oleh Pemerintah atas BagianBagian Tanah yang Merupakan Kelebihan dari Luas Maksimum beserta ketentuan pelaksananya yakni Peraturan Pemerintah Nomor 224 Tahun 1961 tentang Pelaksanaan Pembagian Tanah dan Pemberian Ganti Kerugian. Awalnya Badan Pertanahan 
Nasional Tingkat II Malang menerbitkan 91 Bidang Surat Izin Menggarap dengan ketentuan bahwa tanah tersebut digarap oleh pihak yang bersangkutan. subjek SIM adalah petani/pekebun atau buruh tani dan lain sebagainya sebagaimana yang tertuang dalam Peraturan Pemerintah Nomor 224 Tahun 1961 tentang Pelaksanaan Pembagian Tanah dan Pemberian Ganti Kerugian. Hingga saat ini jumlah penduduk yang ada di dusun Kampung Anyar mencapai 170 Kepala Keluarga. Pemberian Surat Izin Menggarap (SIM) terhadap penduduk Kampung Anyar yang awalnya 91 bidang telah meningkat hingga mencapai 174 bidang. Permasalahan tanah masyarakat desa Sanankerto dengan Perum Perhutani bermula sejak tahun 1980. Dalam konflik ini penulis menganalisis menggunakan teori perlindungan hukum upaya melindungi kepentingan seseorang dengan cara mengalokasikan suatu kekuasaan kepadanya untuk bertindak dalam rangka kepentingannya tersebut (Rahardjo, 2010:121).

Landasan yuridis konsep perlindungan hukum telah termaktub dalam pasal 1 ayat 3 Undang-Undang Dasar 1945 yang menyatakan bahwa Indonesia adalah negara hukum. Dengan adanya ketentuan tersebut, negara telah menjamin perlindungan hukum yang merupakan hak dari setiap warga negara. Philipus M. Hadjon (2007:40) menyatakan bahwa prinsip perlindungan hukum rakyat Indonesia merupakan kombinasi ideologi Pancasila dengan konsep pengakuan dan perlindungan hak asasi manusia. Dalam konflik tenurial ini penulis akan menggunakan perlindungan hukum represif yang mana perlindungan hukum ini menitikberatkan kepada upaya penyelesaian sengketa atau konflik. Metode ini dikhususkan kepada sistem peradilan umum dan administrasi di Indonesia. Prinsip perlindungan hukum represif berpedoman kepada pengakuan dan perlindungan Hak Azasi Manusia.

Dusun Kampung Anyar atau Blok Andeman diyakini oleh Kesatuan Pemangkuan Hutan Malang sebagai salah satu teritori kawasan hutan yang dikelola oleh Perum Perhutani. Pada mulanya delegasi Kesatuan Pemangkuan Hutan meninjau lokasi yang dianggap sebagai teritorinya dengan melihat batas-batas yang ada di wilayah dusun Kampung Anyar Blok Andeman. Sejak Sanankerto terbentuk menjadi sebuah pemerintahan desa pada tahun 1910, belum dijumpai sekalipun Perum Perhutani datang dan mengklaim bahwa blok Andeman adalah wilayah teritori Perum Perhutani. Seluruh masyarakat yang ada di desa Sanankerto mengakui bahwa tanah yang ada di Blok Andeman adalah tanah yang langsung dikuasai oleh negara, sehingga penduduk khususnya di dusun Kampung Anyar secara rutin membayar Iuran Pembangunan Daerah (IPEDA) yang sejak tahun 1985 diubah menjadi Pajak Bumi dan Bangunan kepada pemerintahan Kabupaten Malang setiap bulan atas manfaat yang diperoleh secara langsung dari tanah negara yang dikelola/ digarap masyarakat setempat.

Alasan Perum Perhutani melalui Kesatuan Pemangkuan Hutan datang secara spontan ke Blok Andeman pada tahun 1980 adalah potensi sumber daya alam yang melimpah untuk dikelola. Hal ini terbukti dengan adanya sumber mata air yang digunakan untuk seluruh pengairan desa beserta hutan bambu dengan berbagai varietas yang dapat dijadikan sebagai sumber produksi. Pada saat yang sama Kesatuan Pemangkuan Hutan Malang meminta masyarakat dusun Kampung Anyar untuk menunjukkan bukti kepemilikan atas tanah. Dengan bukti Pajak Bumi dan Bangunan yang dimiliki masyarakat, Kesatuan Pemangkuan Hutan Malang menegaskan bahwa bukti tersebut tidak sah menurut ketentuan perundangundangan yang berlaku.

Kemudian Kesatuan Pemangkuan Hutan Malang menunjukkan beberapa bukti fisik seperti lembaran Laporan Resmi Proyek Perbatasan Tambahan yang diakui oleh Perum Perhutani merupakan tonggak sejarah penguasaan blok Andeman. Bukti yang 
ditunjukkan Perum Perhutani tidak dapat menunjukkan secara absolut bahwa blok Andeman merupakan wilayah kekuasaannya. Seharusnya jika memang dari awal blok Andeman adalah milik Perum Perhutani, mengapa sejak tahun 1910 tidak ada satupun jawatan milik pemerintah kolonial Belanda yang datang untuk mengklaim bahwa blok Andeman adalah wilayahnya. Hal ini menunjukkan bahwa tidak ada satupun bukti milik Perum Perhutani yang sinergi dengan blok Andeman karena kesatuan pemangkuan hutan tidak pernah mengklaim itu dari sejak awal perspektif dari masyarakat penduduk Kampong Anyar.

Masyarakat penduduk Dusun Kampong Anyar Desa Sanankerto merasa bahwa tanah tersebut adalah warisan dari nenek moyang mereka pada zaman dahulu yang dipinjam oleh pihak perhutani untuk dikelola. Tanah dalam kawasan hutan Perum Perhutani (KPH) Malang ini statusnya adalah tanah hutan dengan data-data yang sudah valid yang dimiliki oleh perum Perhutani. Berdasarkan peta yang dimiliki perhutani dilihat dari titik tanah hutan di Jawa, Dusun Kampong Anyar adalah tanah hutan. Kebijakan pemerintah Indonesia untuk mengeksploitasi hutan dalam rangka devisa negara cenderung berpedoman kepada kebijakan pemerintah kolonial Belanda. Negara cenderung melakukan eksploitasi tanpa memperhatikan hak-hak masyarakat yang berada di kawasan hutan, dalam hal ini penulis juga menganalisis menggunakan teori hak bahwa hak terkandung unsur perlindungan, kepentingan dan kehendak. Apabila seseorang memiliki sebidang tanah, maka hukum memberikan hak kepadanya dalam arti bahwa kepentingan orang itu mendapatkan perlindungan. Perlindungan itu selain ditujukan pada kepentingan orang tersebut juga ditujukan pada kehendaknya atas tanah itu. Kehendak yang demikian itu identik dengan kewenangan yang ditimbulkan oleh hukum.

Masyarakat menganggap hutan sebagai jaminan ketahanan pangan (food security). Gangguan ekologi yang datang dari luar hutan dianggap ancaman bagi kehidupan sosial dan ekonomi masyarakat kawasan hutan. Blok Andeman yang telah dikuasai oleh masyarakat desa Sanankerto sejak tahun 1951 merupakan tanah negara. Berdasarkan ketentuan Undang-Undang Nomor 28 Tahun 2009 tentang Pajak dan Retribusi Daerah, blok Andeman dikategorikan kedalam jenis pajak bumi dan bangunan pedesaan dan perkotaan. Dalam pasal 78 aturan tersebut dijelaskan bahwa subjek/ wajib pajak bumi dan bangunan pedesaan dan perkotaan adalah orang pribadi/ badan yang mempunyai/ memiliki/ menguasai/ memperoleh manfaat atas bumi/bangunan. Desa Sanankerto khususnya dusun Kampung Anyar keseluruhan memiliki nomor objek pajak (NOP). Dalam hal ini, keseluruhan tanah rakyat yang disengketakan dengan Perum Perhutani dibebankan pajaknya kepada masyarakat. Masing-masing dari penduduk termasuk Andeman memiliki Surat Pemberitahuan Pajak Terhutang Bumi dan Bangunan (SPPT-PBB). Surat Pemberitahuan Pajak Terhutang Bumi dan Bangunan hanya menentukan bahwa atas objek pajak tersebut dibebankan hutang yang harus dibayarkan oleh subjeknya.

Masyarakat yang menduduki lahan milik negara dibebani pajak P-2 (pedesaan/ perkotaan). SPPT-PBB bukan merupakan bukti pemilikan objek pajak. Bukti pemilikan yang sah atas tanah adalah sertifikat tanah yang diterbitkan Badan Pertanahan Nasional berdasarkan Peraturan Pemerintah Nomor 24 Tahun 1997 tentang Pendaftaran Tanah. Blok Andeman dengan luas 94,8 Ha merupakan tanah negara. Apabila Perum Perhutani menyatakan bahwa objek sengketa tersebut merupakan kewenangan pengelolaannya, maka seharusnya badan usaha milik negara (BUMN) tersebut membayar pajak P-3 (perkebunan, perhutanan dan pertambangan) sebagaimana yang telah dituangkan dalam Peraturan Direktur Jendral Pajak Nomor 
PER-36/PJ/2011 tentang Pengenaan Pajak Bumi dan Bangunan Sektor Perhutanan.

Perum Perhutani tidak terdaftar sebagai subjek pajak atas blok Andeman yang merupakan objek sengketa. Hal tersebut menunjukkan bahwa Perum Perhutani tidak memiliki kewenangan pengelolaan apapun terhadap blok Andeman. Kemudian berkaitan pajak P-2 yang dibebankan kepada masyarakat desa Sanankerto telah terdaftar oleh Dinas Pendapatan, Pengelolaan Keuangan dan Aset Kabupaten Malang dengan kode 35.07.120.013 (Daftar Himpunan Ketetapan Pajak Desa Sanankerto buku I, II, III, dan IV Tahun, 2017:3). Dasar PBB P-2 tersebut juga dijadikan landasan oleh masyarakat desa Sanankerto khususnya dusun Kampung Anyar untuk mengajukan redistribusi tanah negara yakni blok Andeman. Permohonan redistribusi tanah mencakup 174 bidang dengan luas 94,8 Ha. Masing-masing dari bidang tersebut telah dilekati PBB P-2.

Masyarakat layak untuk mengajukan redistribusi tanah atau penataan ulang dengan meninjau dari Peraturan Presiden Nomer 86 Tahun 2018 Tentang Reforma Agraria yakni penataan kembali struktur penguasaan, pemilikan, penggunaan, dan pemanfaatan tanah yang lebih berkeadilan melalui Penataan Aset dan disertai dengan Penataan Akses untuk kemakmuran rakyat Indonesia, dalam Pasal 1 ayat 4 yaitu Tanah Objek Reforma Agraria yang selanjutnya disingkat TORA adalah tanah yang dikuasai oleh negara dan/atau tanah yang telah dimiliki oleh masyarakat untuk diredistribusi atau dilegalisasi. Tanah negara tersebut yang telah didudukinya sejak tahun 1951. Dasar yuridis yang dimaksud telah dituangkan dalam Peraturan Menteri Negara Agraria/ Kepala Badan Pertanahan Nasional nomor 09 Tahun 1999 tentang Tata Cara Pemberian dan Pembatalan Hak atas Tanah Negara dan Hak Pengelolaan. Dalam pasal 2 dijelaskan bahwa pemberian hak atas tanah negara meliputi hak milik, hak guna usaha, hak guna bangunan, hak pakai dan hak pengelolaan.
Sebelum mengajukan permohonan hak, terlebih dahulu harus data yuridis dan data fisik sebagaimana yang tertuang dalam pasal 9 aturan tersebut. Salah satu data fisik bisa berupa pajak PBB P-2, surat girik, IPEDA maupun bukti peroleh penggunaan tanah negara lainnya. Akan tetapi dari penjelasan diatas tersebut hanya sebagai syarat sertifikasi saja bukan merupakan bukti kepemilikan atas tanah, Menanggapi hal tersebut, redistribusi tanah terhadap objek sengketa tersebut menjadi urgensi untuk menunjang keberlangsungan hidup penduduk desa Sanankerto.

Berdasarkan Peraturan Pemerintah Nomor 224 Tahun 1961 tentang Pelaksanaan Pembagian Tanah dan Pemberian Ganti Kerugian pasal 1 huruf(d) yang menegaskan bahwa tanah-tanah yang akan dikategorikan sebagai objek landreform adalah tanahtanah yang langsung dikuasai oleh negara. Kemudian dalam Keputusan Kepala Badan Pertanahan Nasional Nomor 25 tahun 2002 tentang Pedoman Pelaksanaan Permohonan Penegasan Tanah Negara menjadi Objek Pengaturan Penguasaan Tanah/ Landreform bagian II poin (4) ditegaskan bahwa tanahtanah yang akan menjadi objek landreform termasuk tanah-tanah kehutanan yang telah digarap oleh rakyat dan telah dilepaskan haknya oleh instansi yang bersangkutan. Namun dalam hal ini yang mana objek sengketa ini adalah konflik tenurial dan status hak atas tanah tersebut adalah tanah dalam kawasan Hutan Perum Perhutani (KPH) Malang. Tujuan utama Landreform adalah meningkatkan kondisi sosial ekonomi rakyat terhadap produktivitas nasional khususnya sektor pertanian. Hal ini tentunya sesuai dengan kondisi desa Sanankerto dimana mayoritas penduduknya bermata pencaharian petani/ pekebun. Salah satu implikasi yang akan dirasakan petani/ pekebun di desa tersebut adalah peningkatan kinerja sektor pertanian dengan adanya jaminan hak mengenai pemilikan tanah berupa pembatasan hak-hak individu atas 
sumber-sumber tanah yang ada di blok Andeman (Dusun Kampung Anyar).

Permasalahan sengketa kawasan hutan antara Perum Perhutani dengan masyarakat desa Sanankerto telah berlangsung sejak tahun 1980. Melalui Kesatuan Pemangkuan Hutan Malang, Perum Perhutani berusaha melakukan upaya perlindungan dan pengembalian fungsi hutan yang ada di wilayah Turen, Kabupaten Malang. Blok Andeman merupakan salah satu kawasan hutan yang dikelola oleh Perum Perhutani. Sebelum masa kemerdekaan Republik Indonesia pada tahun 1945, Perum Perhutani telah terbentuk berdasarkan Keputusan Pemerintah (Gouvernement Besluit) tertanggal 09 Februari 1897 dalam Bijblad 5164 sebagai jawatan kehutanan Belanda (Dienst van het Boschwezen). Jawatan kehutanan tersebut segera berakhir sejak Indonesia memproklamasikan kemerdekaannya dengan melimpahkan kewenangan pengelolaan hutan yang ada di Indonesia kepada Jawatan Kehutanan Indonesia.

Perum Perhutani merupakan Badan Usaha Milik Negara (BUMN) yang awalnya berada di bawah Departemen Kehutanan dengan tugas pengelolaan hutan di Pulau Jawa, khususnya jawa tengah dan jawa timur sejak tahun 1972 berdasarkan Peraturan Pemerintah Nomor 15 Tahun 1972 tentang Pendirian Perusahan Umum Kehutanan Negara. Kemudian diperluas dengan adanya kawasan hutan di jawa barat berdasarkan Peraturan Pemerintah Nomor 02 Tahun 1978 tentang Penambahan Unit Produksi Perusahaan Umum Kehutanan Negara. Jika ditinjau secara historis, Perum Perhutani memiliki fungsi strategis dalam pemberian kontribusi kepada negara dalam bentuk pundi-pundi penerimaan negara. Upaya perlindungan, pelestarian dan pemberdayaan hutan menjadi tugas dari Perum Perhutani. Kasus yang dihadapi oleh Perum Perhutani dengan masyarakat desa Sanankerto adalah konflik tenurial/kawasan hutan yakni pendudukan hutan wilayah kerja Perum
Perhutani secara ilegal.

Berdasarkan Suppletoir Grens Project Proces-Verbaal (Laporan Resmi Proyek Perbatasan Tambahan) yang diterbitkan oleh Pemerintah Kolonial Belanda terhadap Dienst van het Boschwezen (Jawatan Kehutanan Belanda) tertanggal 29 Juni 1933, dengan berpedoman kepada Gouvernement Besluit (Keputusan Pemerintah) tanggal 9 Februari 1897 nomor 21, termuat dalam Bijblad 5164 tentang Afbakening/ Pemancangan, Pengukuran, Pemetaan dan Penataan Hutan, serta kesetujuan dan pengakuan dari R. Soedono selaku Camat Turen, A. Wempe selaku Kepala Pemerintahan Tingkat II Malang (Controleur van Malang) dan R. Ardjodinoto selaku Camat Bululawang bahwa Blok Andeman yang ada di Sanankerto merupakan kawasan hutan yang menjadi hak kelola Jawatan Kehutanan Belanda (Dienst van het Boschwezen).

Sejak tahun 1980 masyarakat desa Sanankerto menolak mengakui bahwa blok Andeman merupakan kawasan hutan wilayah kerja Perum Perhutani. Alasan pertama masyarakat bersikukuh bahwa blok Andeman adalah tanah yang dikuasai langsung oleh negara. Masyarakat desa Sanankerto masih menggunakan pemahaman bahwa blok Andeman merupakan tanah negara bebas yakni tanah-tanah negara yang belum pernah dilekati hak atas tanah. Padahal dengan adanya Suppletoir Grens Project Proces-Verbaal (Laporan Resmi Proyek Perbatasan Tambahan) menunjukkan bahwa blok Andeman sebelum dihuni oleh dusun Kampung Anyar pada tahun 1951 adalah hutan yang dikelola oleh jawatan kehutanan Belanda.

Perlu diketahui bahwa konsep tanah negara bebas telah dihapus semenjak diberlakukan Undang-Undang Nomor 05 Tahun 1960 tentang Peraturan Dasar Pokok Agraria. Alasan kedua masyarakat desa Sanankerto berasumsi bahwa mereka telah menetap dan membentuk pemerintahan desa sejak tahun 1910, dan Kampung 
Anyar/ Kertomulyo telah dihuni masyarakat sejak tahun 1951, kemudian masyarakat beranggapan bahwa Perum Perhutani baru berdiri pada tahun 1959. Sehingga timbul sebuah persepsi masyarakat tentang bagaimana bisa Perum Perhutani mengklaim bahwa blok Andeman adalah wilayahnya, sedangkan Badan Usaha Milik Negara tersebut baru terbentuk pada tahun 1959 . Oleh karenanya masyarakat berhak untuk mengelola dan menerima manfaat yang ada di Blok Andeman tanpa gangguan dari pihak manapun.

Kawasan hutan merupakan lahan yang secara legal dikuasakan oleh negara kepada Perum Perhutani untuk dikelola secara komersiil dengan tujuan memperoleh profit yang sebesar-besarnya. Dalam pasal 3 ayat (1) Undang-Undang Nomor 41 Tahun 1999 tentang Kehutanan, ditegaskan bahwa penyelenggaraan kehutanan bertujuan untuk sebesar-besarnya kemakmuran rakyat yang berkeadilan dan berkelanjutan dengan menjamin keberadaan hutan dengan luasan yang cukup dan sebaran yang proporsional. Berdasarkan fakta empiris, tak jarang ditemukan masyarakat secara illegal menduduki kawasan hutan/okupasi illegal. Hal ini berdampak terhadap luasan hutan yang berdasarkan fakta yang dikemukakan oleh pihak Perum Perhutani di atas kurang dari $30 \%$.

Berdasarkan substansi pasal 18 ayat (1) aturan kehutanan yang berbunyi: pemerintah menetapkan dan mempertahankan kecukupan luas kawasan hutan untuk setiap pulau guna optimalisasi manfaat lingkungan, manfaat sosial dan manfaat ekonomi masyarakat setempat. Kemudian ayat (2) ditegaskan bahwa maksud dari kecukupan luas kawasan hutan sebagaimana yang tertuang dalam ayat (1) minimal 30\% (tiga puluh persen) dengan sebaran yang proporsional. Sengketa tanah yang melibatkan Perum Perhutani dengan masyarakat desa Sanankerto merupakan konflik tenurial (lahan) kawasan hutan yang disebabkan oleh tumpang tindih klaim penguasaan blok Andeman dari masingmasing pihak.

Faktor utama penyebab tumpang tindih klaim sebagaimana yang dimaksud di atas adalah ketidakjelasan tata batas hak pengusahaan hutan (HPH). Pada dasarnya, Perum Perhutani mengklaim berhak secara legal atas blok Andeman karena telah memperoleh izin konsesi dari pemerintah, sedangkan masyarakat desa Sanankerto secara tradisional telah lama mengelola lahan di areal tersebut. Penting diketahui bahwa blok Andeman yang berstatus tanah negara merupakan kawasan hutan negara. Hal tersebut ditegaskan dalam Pasal 5 Undang-Undang Nomor 41 Tahun 1999 tentang Kehutanan. Kemudian merujuk pada tugas Departemen Kehutanan yang akan menetapkan bahwa tidak ada hak privat (Private Rights) terhadap kawasan hutan negara. Hal ini berarti blok Andeman tidak boleh dilekati hak apapun karena merupakan hutan negara.

\section{Status Hak Atas Tanah Penduduk Desa Dalam Kawasan Hutan Perum Perhutani (KPH) Ditinjau dari Peraturan Presiden Nomor 86 Tahun 2018 Tentang Reforma Agraria}

Penguasaan tanah mengatur tentang kemungkinan penggunaan, syarat-syarat untuk dapat menggarap tanah, dan jangka waktu penguasaan tanah berlangsung. Hal ini berkaitan dengan subjek dan objek hak atas tanah penguasaan tanah yang memberikan hak, kewajiban dan/atau larangan bagi pemegangnya untuk berbuat sesuatu mengenai tanah yang dikuasainya. Hak dan kewajiban merupakan landasan bagi subjek hukum untuk melakukan berbagai tindakan yang berhubungan dengan tanah. Aturan-aturan yuridis menjadi acuan untuk mengatur hak dan kewajiban yang berhubungan dengan tanah. Penguasaan hak atas tanah yang dilakukan oleh masyarakat penduduk Dusun Kampung Anyar, Desa Sanankerto didasari oleh keyakinan masyarakat bahwa 
tanah dalam kawasan hutan merupakan tanah warisan dari nenek moyang oleh para Penjajah Belanda pada tahun 1920-1930.

Tanah yang dimaksud bahwa tanah tersebut merupakan tanah warisan orang tua terdahulu yang dapat dipergunakan untuk pertanian. Pada zaman sekelompok orang atau individu yang menempati dan meninggalkan kawasan hutan adalah hal yang biasa dan tidak melahirkan hak kepemilikan atas tanah di kawasan hutan tersebut. Perkembangan masyarakat mengubah tata nilai yang melahirkan hak atas tanah bagi masyarakat yang membuka tanah dengan ijin aparat Pemerintah Desa. Penguasaan tanah dengan jalan membuka tanah yang digarap secara terus menerus dapat melahirkan kepemilikan atas tanah tersebut. Penguasaan ini menggariskan bahwa Departemen Kehutanan berwenang melakukan tindakan pengurusan hutan, perencanaan hutan dan menentukan hubungan hukum antara subjek dengan hutan. Penentuan hubungan hukum antara hutan dengan subjek hukum meliputi penentuan status kawasan hutan termasuk tukar menukar kawasan hutan.

Penentuan status kawasan hutan merupakan bentuk menetapkan yuridiksi kewenangan Departemen Kehutanan untuk mengurus hutan. Konsekuensi logis dari adanya penetapan kawasan hutan adalah kewajiban pemerintah dalam hal ini Departemen Kehutanan untuk mengurus dan melindungi hutan serta mewajibkan masyarakat untuk menjaga hutan. Kewenangan ini menyangkut pengukuhan kawasan hutan dan perubahan kawasan hutan. Penetapan kawasan hutan diatur sampai Pasal 16 Undang- undang Kehutanan. Pengukuhan kawasan hutan dilakukan melalui Surat Keputusan Menteri, dengan terlebih dahulu melakukan proses "penunjukan kawasan hutan, penataan batas kawasan hutan, pemetaan kawasan hutan, dan penetapan kawasan hutan".

Berdasarkan statusnya hutan dibedakan menjadi dua yaitu hutan hak dan hutan negara.
Hutan negara adalah "hutan yang berada pada tanah yang tidak dibebani hak atas tanah". Hutan hak adalah "hutan yang berada pada tanah yang dibebani hak atas tanah". Tukar menukar kawasan hutan merupakan bagian dari kewenangan pemerintah untuk mengatur hubungan hukum antara pemerintah dengan hutan, melalui jalan melepaskan kawasan hutan dan memasukan kawasan hutan baru sebagai penggantinya. Aturan mengenai tukar menukar kawasan hutan diatur dalam Keputusan Menteri Pertanian Nomor $178 / \mathrm{Kpts} / \mathrm{UM} / 4 / 1975$ tentang Pedoman Umum Perubahan Kawasan Hutan. Aturan tersebut kemudian dirubah melalui Keputusan Menteri Kehutanan Nomor 164/Kpts-II/1994 tentang Pedoman Tukar Menukar Kawasan Hutan. Aturan tersebut kemudian diperbaharui melalui Keputusan Menteri Kehutanan Nomor 292/Kpts-II/1995 tentang Tukar Menukar Kawasan Hutan dan diganti melalui Peraturan Menteri Kehutanan Nomor: P. 32/Menhut -II/2010 Tentang Tukar Menukar Kawasan Hutan.

Kawasan Hutan yang tidak dilepas oleh Kementerian Kehutanan tidak akan pernah bisa menjadi hak milik yang dapat diterbitkan sertifikatnya oleh Badan Pertanahan. Peraturan Presiden Nomer 86 Tahun 2018 Tentang Reforma Agraria mengatur tentang penataan kembali struktur penguasaan, pemilikan, penggunaan, dan pemanfaatan tanah yang lebih berkeadilan melalui penataan aset dan disertai dengan penataan akses untuk kemakmuran rakyat Indonesia. Tanah dalam kawasan hutan yang akan dilepas tetap akan mendapatkan ganti atau tukar guling karena hutan di Jawa hingga saat ini belum mencapai 30\%. Konflik yang sampai saat ini masih dalam proses pengajuan berkaitan dengan usulan dari pihak Perum Perhutani untuk bekerjasama sebagai perhutanan sosial. Masyarakat tetap berjuang untuk dapat menguasai tanah tersebut menjadi hak milik atas tanah. Alasannya karena masyarakat telah menempatinya selama bertahun-tahun. 
Ketentuan yang memperkuat argumen masyarakat adalah Pasal 24 ayat (2) Peraturan Pemerintah Nomor 24 Tahun 1997 Tentang pendaftaran tanah. Ketentuan tersebut ditafsirkan oleh masyarakat desa sekitar hutan tersebut bahwa jika mereka telah menguasai tanah tersebut selama 20 tahun

\section{SIMPULAN}

1. Konflik kepemilikan tanah antara masyarakat dengan Perum Perhutani berkaitan dengan hak atas tanah yang berada di kawasan lahan Perum Perhutani bermula sejak jaman penjajahan Belanda. Masyarakat dalam waktu yang lama, sejak penjajahan dan setelah kemerdekaan menempati Kawasan tersebut secara turun temurun. BPN menerbitkan surat Ijin Memanfaatkan lahan untuk meningkatkan ekonomi masyarakat. Masyarakat membayar SPPT-PBB terhadap lahan yang ditempatinya. Bukti pembayaran pajak dan penempatan lahan secara fisik yang sudah turun temurun menjadi alat bukti masyarakat untuk mengklaim kepemilikan tanah. Sedangkan Perhutani mengklaim tanah tersebut menjadi miliknya berdasarkan peta.

\section{DAFTAR RUJUKAN}

Fadhilah, Nurul Laili. 2016. Implikasi Pemberlakuan UU Nomor 9 Tahun 2015 tentang Perubahan Kedua UndangUndang Nomor 23 Tahun 2014 tentang Pemerintah Daerah Atas Perizinan Pertambangan terhadap Legislasi di Daerah. Jurnal Ilmiah Pendidikan Pancasila dan Kewarganegaraan. (Online), Volume 1, Nomor 2, Halaman 91-101, Desember 2016 (http:// journal2.um.ac.id/index.php/jppk/ article/view/826/491, diakses pada 30 Maret 2019)

Hadjon, Philipus M. 2007. Perlindungan Hukum Bagi Rakyat di Indonesia. Edisi Revisi. Bina Ilmu. Surabaya. dengan iktikat baik dapat memperoleh hak milik atas tanah yang bersangkutan. Akan tetapi peraturan ini dapat berlaku jika tanah yang ditempati itu bukan tanah sengketa atau konflik dan tanah ini adalah tanah dalam kawasan Hutan Perum Perhutani (KPH) Malang jadi ini tidak dapat berlaku.

Status hak atas tanah penduduk desa dalam kawasan hutan Perum Perhutani $(\mathrm{KPH})$ ditinjau dari Peraturan Presiden Nomor 86 Tahun 2018 Tentang Reforma Agraria tidak dapat didaftarkan sebagai hak milik oleh masyarakat. Hal tersebut berdasarkan pada ketentuan peraturan tersebut yang memiliki semangat untuk melakukan penataan kembali struktur penguasaan, pemilikan, penggunaan, dan pemanfaatan tanah yang lebih berkeadilan melalui penataan aset dan disertai dengan penataan akses untuk kemakmuran rakyat Indonesia. Kepemilikan hak atas tanah dapat diperoleh oleh masyarakat apabila Kementerian Kehutanan melepaskan tanah tersebut atau masyarakat dapat mendapatkan penggantian tanah di tempat lain (tukar guling).

Moleong, Lexy J. 2002. Metodologi Penelitian Kualitatif. Remaja Rosda karya. Bandung.

Muhammad, Abdul kadir. 2004. Hukum dan Penelitian Hukum. Citra Aditya Bakti. Bandung.

Noor, Fitrian. 2018. Pengelolaan Sumber Daya Alam Berdasar Prinsip Fiqh Al-Bi'ah. Jurnal Ilmiah Pendidikan Pancasila dan Kewarganegaraan. (Online), Volume 3, Nomor 1, Halaman 47-55, Juni 2018 (http://journal2. um.ac.id/index.php/jppk/article/ view/6040/3096, diakses pada 27 Februari 2019)

Pamulardi, Bambang. 2005. Hukum Kehutanan 
dan Pembangunan Bidang Kehutanan. Raja Grafindo Persada. Jakarta.

Rahardjo, Satjipto Raharjo. 2010. Sisi Lain dari Hukum di Indonesia. Kompas: Jakarta.

Saukah, Ali dkk. 2002. Pedoman Penukisan Karya Ilmiah Skripsi, Tesis, Disertasi, Artikel, Makalah, Laporan penelitian. Universitas Negeri Malang. Malang. Subana, M dan Sudrajat, 2001. Dasar-Dasar Penelitian Ilmiah. CV. Pustaka Setia. Bandung

Sudjana, Nana. 1989. Penelitian dan Penelitian
Pendidikan. Sinar Baru. Bandung. Sumardjono, Maria SW. 2011. Tanah dalam Perspektif Hak Ekonomi, Sosial dan Budaya. Penerbit Buku Kompas. Jakarta.

Supriadi. 2010. Hukum Kehutanan dan Hukum Perkebunan di Indonesia. PT. Sinar Grafika. Jakarta.

Supriyadi, Bambang Eko. 2013. Hukum Agraria Kehutanan: Aspek Hukum tentang Pertanahan dalam Pengelolaan Hutan Negara. Edisi I. Rajawali Pers: Jakarta. 